\title{
EFEKTIVITAS MEDIA E-LEARNING DENGAN METODE GUIDED DISCOVERY DITINJAU DARI KEMANDIRIAN BELAJAR MATEMATIKA SISWA
}

\author{
Ulfa Lu'luilmaknun', Dhoriva Urwatul Wutsqa ${ }^{2}$ \\ ${ }^{1,2}$ Pendidikan Matematika, Universitas Negeri Yogyakarta \\ E-mail: $\quad \frac{\text { ulfa.luluilmaknun2016@student.uny.ac.id }}{\text { dhoriva_uw@uny.ac.id }}$
}

Received 9 October 2018; Received in revised form 11 November 2018; Accepted 26 December 2018

\begin{abstract}
This study aims to discover the effect of e-learning media with guided discovery learning method of students' self regulated learning in mathematics. The study employed quasi-experimental method using two classes which are experiment and control class. The subject of this study are 79 eight grade students. The instrument used is self regulated learning questionnaire. The learning process of the experiment class implement only e-learning media with guided discovery method while the control class implement only guided discovery method. The result shows that students' self regulated learning in the experiment class higher than the control class. It can be concluded that e-learning media with guided discovery method is effective based on students' self regulated learning in mathematics.
\end{abstract}

Keywords: E-learning media, Guided discovery method, Self regulated learning

\section{PENDAHULUAN}

Matematika adalah ilmu pengetahuan yang dapat diaplikasikan pada setiap bidang kehidupan. Matematika adalah keterampilan mendasar dalam kehidupan sehari-hari kita (Ku, Chen, Wu, Lao, dan Chan, 2014). Oleh karena itu, siswa penting untuk mempelajari dan memahami matematika.

Terdapat tiga domain dalam taksonomi Bloom yang dibuat untuk tujuan pendidikan, yaitu domain kognitif, domain afektif, dan domain psikomotorik (Cullinane, 2010). Salah satu domain afektif yang penting dimilki oleh setiap siswa dalam pembelajaran matematika yaitu kemandirian belajar. Pembelajaran yang dianjurkan pada zaman sekarang ini adalah pembelajaran yang berpusat pada siswa. Pembelajaran yang berpusat pada siswa dapat terlaksana dengan baik ketika siswa memiliki kemampuan kemandirian belajar yang baik pula.
Kemandirian belajar adalah kemampuan dimana siswa dapat mengendalikan perilakunya serta dapat mengatur dan mengevaluasi pembelajarannya sendiri sebagai upaya mencapai tujuan pembelajaran (Timmons, Pelletier, \& Corter, 2015; Day \& Connor, 2016; Gunzenhauser \& von Suchodoletz, 2015; Pintrich, 2000; Marchis, 2011; Zimmerman, 1990; Artelt, Baumert, McElvany, \& Peschar, 2003; Follmer \& Sperling, 2016). Pentingnya kemandirian belajar juga telah diungkapkan oleh beberapa peneliti seperti de Corte, Depaepe, Eynde, dan Verschaffel (2011) dan Fadlelmula (2010) menyatakan bahwa kemandirian belajar dikenal sebagai kunci pembelajaran dalam pendidikan matematika.

Kemandirian belajar penting dimiliki oleh siswa, namun pada kenyataanya bahwa kemampuan kemandirian belajar yang dimiliki oleh siswa pada pembelajaran matematika 
masih rendah. Dari penelitian oleh Marchis (2011) Jumaisyaroh, Napitupulu, dan Hasratuddin (2015), Sumartono dan Zubaidah (2016), Azka dan Santoso (2015) menunjukkan bahwa beberapa siswa masih memiliki kemampuan kemandirian belajar yang rendah.

Selain strategi atau model pembelajaran, media pembelajaran adalah salah satu unsur yang sangat penting bagi keberhasilan proses belajar mengajar. Salah satu media pembelajaran yang dapat digunakan adalah media pembelajaran berbasis teknologi. Teknologi sudah dimanfaatkan pada berbagai bidang kehidupan tidak terkecuali dalam bidang pendidikan, khususnya dalam pembelajaran matematika. Pemanfaatan ICT (Information and Communication Technology) dapat membantu siswa dalam pembelajaran matematika (Rohendi, 2012).

Salah satu pemanfaatan ICT dalam pembelajaran yaitu menggunakan e-learning. E-learning didefinisikan sebagai media pembelajaran memanfaatkan teknologi bantuan komputer yang dikombinasikan dengan jaringan telekomunikasi (Repolusk, 2009). Konsep e-learning adalah pembelajaran elektronik memuat semua bentuk perangkat elektronik yang digunakan dalam proses belajar mengajar dan membuat belajar menjadi lebih mudah, contoh perangkat meliputi komputer dan fasilitas audio visual lainnya (Etukudo \& Elijah, 2012).

Kemandirian belajar tidak diperoleh secara spontan, tetapi dapat dikembangkan melalui partisipasi dalam pengalaman dan lingkungan yang memberi kesempatan bagi siswa untuk mengatur pembelajaran mereka sendiri (Kramarski \& Michalsky, 2009). Salah satu cara untuk memfasilitasi siswa untuk berpartisipasi dalam pengalaman dan lingkungan adalah menggunakan media yang berbasis teknologi. Kitsantas (2013) dan McFarlane (2001) mengatakan bahwa pembelajaran menggunakan teknologi dapat melatih kemandirian belajar siswa. Pembelajaran menggunakan media $e$ learning dapat membuat siswa mengembangkan kemampuan kemandirian belajar dengan bertanggung jawab atas pembelajaran mereka sendiri, siswa secara aktif berperan dalam proses pembelajaran, menetapkan tujuan pembelajaran, memantau, dan mengevaluasi hasil belajar (Zhao \& Chen, 2016). Oleh karena itu, menggunakan media $e$ learning pada pembelajaran matematika diharapkan dapat melatih kemandirian belajar siswa.

Menurut Garrison dan Kanuka (2004) terdapat tiga jenis e-learning yaitu enhanced, blended, dan online. Dalam penelitian ini, akan digunakan pembelajaran dengan enhanced $e$ learning. Pembelajaran dengan enhanced e-learning yang dimaksud pada penelitian ini adalah media $e$ learning digunakan sebagai fasilitas tambahan dalam pembelajaran matematika.

Dalam pembelajaran matematika, metode discovery adalah salah satu metode yang berpusat pada siswa. Yang, Liao, Ching, Chang, dan Chan (2010) menyatakan bahwa metode discovery adalah salah satu metode yang mengurangi peran guru dan membuat siswa membangun pengetahuannya sendiri. Metode discovery mendorong siswa untuk aktif dalam proses pembelajaran dan dapat mengembangkan kemandirian belajar (Khan, 2014).

Menurut Mayer (2002) terdapat tiga jenis metode discovery yaitu pure discovery, guided discovery, expository instruction. Alfieri, Brooks, Aldrich,

\section{4 | AKSIOMA}

Jurnal Pendidikan Matematika FKIP Univ. Muhammadiyah Metro 
dan Tenenbaum (2011: 2) menyatakan bahwa metode discovery kurang efektif jika tidak ada arahan dari guru atau dengan kata lain guided discovery lebih efektif daripada pure discovery. Oleh karena itu, peneliti memilih menggunakan metode guided discovery. Dalam guided discovery, siswa menerima masalah untuk dipecahkan dengan guru memberikan petunjuk bagaimana memecahkan permaslahan tersebut agar siswa tetap pada arah yang benar (Mayer, 2002). Langkah-langkah metode guided discovery menurut Achera, Belecina, \& Garvida (2015) yaitu motivation, exploration, presentation, warp up, practice dan evaluation

Penggunaan media e-learning dalam pembelajaran di luar kelas dapat dikombinasikan dengan metode guided discovery untuk pembelajaran di dalam kelas. Media e-learning dapat dikombinasikan dengan metode guided discovery yang dapat mengurangi tingkat kegagalan siswa dalam belajar (Khan, 2014). Dalgarno, Kennedy, dan Bennett (2014) merekomendasikan pembelajaran menggunakan media $e$ learning (computer based simulation) dikombinasikan dengan metode guided discovery.

Terdapat penelitian-penelitian terdahulu tentang pemanfaatan teknologi pada pembelajaran. Penelitian oleh Dabbagh dan Kitsantas (2005) menunjukkan bahwa pembelajaran melalui web dapat membantu meningkatkan kemampuan kemandirian belajar mahasiswa umur 22 hingga 45 tahun. Penelitian oleh Chen (2009) menunjukkan bahwa e-learning dapat melatih kemandirian belajar siswa kelas IV pada mata pelajaran bilangan pecahan. Penelitian oleh Lazakidou dan Retalis (2010) menunjukkan bahwa computer based instructional dapat mengembangkan kemandirian belajar siswa kelas IV pada pembelajaran matematika. Penelitian oleh Barak, Hussein-Farraj, dan Dori (2016) menunjukkan bahwa pembelajarn online memiliki efek positif terhadap pengembangan kemandirian belajar mahasiswa ilmu pengetahuan dan teknik.

Adapun penelitian-penelitian mengenai pembelajaran dengan metode discovery learning. Penelitian oleh Khan (2014) tentang pembelajaran menggunakan guided discovery dan blended learning dengan sistem manajemen pembelajaran di dalam dan di luar kelas untuk meningkatkan pembelajaran mahasiswa Program Bisnis. Penelitian oleh Imawan (2015) bertujuan untuk mendeskripsikan keefektifan dan perbedaan keefektifan antara model guided discovery learning (GDL) dan model project-based learning $(\mathrm{PjBL})$ ditinjau dari prestasi belajar, kepercayaan diri, dan keterampilan berpikir kritis mahasiswa pada mata kuliah geometri ruang. Penelitian oleh Sunismi (2015) bertujuan untuk mengembangkan pembelajaran guided discovery materi Kalkulus II dengan menerapkan mobile mathematics learning (MML).

Dari penelitian-penelitian yang telah diuraikan terlihat bahwa masih sedikitnya penelitian yang mengkombinasikan media e-learning dengan metode guided discovery yang bertujuan melatih kemandirian belajar siswa pada pembelajaran matematika. Oleh karena itu, penelitian mengenai efektivitas media e-learning dengan metode guided discovery ditinjau dari kemandirian belajar matematika siswa penting dilakukan untuk memperkuat bukti empiris dari hasil penelitianpenelitian yang diuraikan di atas. Tujuan dari penelitian ini adalah untuk mengetahui efektivitas media e-learning dengan metode guided discovery 
ditinjau dari kemandirian belajar matematika siswa.

\section{METODE PENELITIAN}

Jenis penelitian ini adalah kuasi eksperimen dengan nonequivalent comparison-group design. Desain ini menggunakan dua kelas yaitu kelas eksperimen dan kelas kontrol. Kelas eksperimen diberi perlakuan berupa pembelajaran dengan metode guided discovery dan menggunakan media $e$ learning. Kelas kontrol diberi perlakuan berupa pembelajaran dengan metode guided discovery tetapi tidak tidak menggunakan media e-learning. Kelas eksperimen dan kelas kontrol masingmasing diberikan pretest (angket awal) sebelum pembelajaran dan posttest (angket akhir) setelah pemberian tindakan.

Penelitian dilaksanakan di SMP Negeri 6 Mataram, Nusa Tenggara Barat pada tanggal 5 Februari sampai 10 Maret 2018. Populasi pada penelitian ini adalah seluruh siswa kelas VIII SMPN 6 Mataram yang berjumlah 11 kelas dan telah mempelajari materi garis dan sudut dan teorema pythagoras serta belum mempelajari materi lingkaran untuk tingkat SMP. Kemudian sampel dipilih secara acak, yaitu kelas VIII F sejumlah 40 siswa sebagai kelas eksperimen dan kelas VIII G sejumlah 39 siswa sebagai kelas kontrol.

Pembelajaran di kelas eksperimen menggunakan media e-learning dengan metode guided discovery. Pembelajaran dilakukan di dalam dan di luar kelas. Pembelajaran di dalam kelas menggunakan langkah-langkah metode guided discovery serta media e-learning digunakan hanya sebagai enhanced atau tambahan pada pembelajaran di kelas. Pada tahap motivation, guru membantu siswa mengingat informasi untuk menghubungkan pengetahuan yang dimiliki siswa sebelumnya dengan pengetahuan baru yang didapat. Pada tahap exploration, para siswa bekerja dalam kelompok dan dibantu oleh guru untuk mendiskusikan seluruh persoalan pada Lembar Kerja Siswa (LKS). Pada tahap presentation, salah satu anggota kelompok diminta untuk mempresentasikan dan mendiskusikan jawaban mereka. Pada tahap warp up, guru mengajukan pertanyaan kepada siswa untuk mengethauui sejauh mana siswa memahami materi. Pada tahap practice, siswa menyelesaikan question of the day yang diberikan oleh guru dimana questionn of the day tersedia dalam aplikasi schoology. Setelah siswa menyelesaikan question of the day, siswa akan langsung dapat melihat skor yang didapatkannya di schoology. Tahap evaluation dilakukan pada akhir materi pembelajaran, dimana guru memberikan angket kemandirian belajar, tes pemahaman konsep dan pemecahan masalah kepada siswa.

Pembelajaran di luar kelas dilakukan setelah pembelajaran di kelas dan tidak memakai alokasi waktu pembelajaran dimana kegitan guru dan siswa yaitu berdiskusi mengenai materi lingkaran pada forum diskusi di schoology. Diskusi di schoology tidak memiliki jadwal yang ditentukan sehingga siswa bebas berdiskusi kapanpun dan dimanapun.

Pembelajaran di kelas kontrol hanya menggunakan metode guided discovery dan pembelajaran hanya dilakukan di dalam kelas. Kegiatan pada setiap tahap metode guided discovery di kelas kontrol hampir sama dengan kegiatan pada setiap tahap metode guided discovery di kelas eksperimen tetapi yang membedakan adalah pada kegiatan exploration dan practice. Pada tahap exploration, para siswa bekerja dalam kelompok dan dibantu oleh guru untuk mendiskusikan persoalan pada LKS. Pada tahap practice, siswa pada

\section{6 | AKSIOMA}

Jurnal Pendidikan Matematika FKIP Univ. Muhammadiyah Metro 
kelas kontrol tidak diberikan questin of the day tetapi siswa hanya menyelesaikan soal pada LKS yang diberikan guru.

Untuk mengetahui kemandirian belajar siswa dalam pembelajaran matematika digunakan instrumen berupa angket kemandirian belajar. Angket terdiri dari 24 butir pernyataan. Kemampuan kemandirian belajar siswa yang diukur pada penelitian ini adalah kemampuan mengendalikan prilaku, mengatur pembelajran, dan mengevaluasi pembelajaran.

Bukti validitas angket kemandirian belajar menggunakan face validity dan analisis faktor. Hasil face validity angket kemandirian belajar siswa terbukti valid dan dinyatakan layak digunakan setelah revisi oleh ahli. Hasil analisis faktor angket kemandirian belajar siswa terdiri dari 24 butir pernyataan, diperoleh nilai KaiserMeyer-Olkin (KMO) sebesar 0,734. Hal ini membuktikan bahwa seluruh butir pernyataan di dalam angket dapat digunakan.

Estimasi reliabilitas angket kemandirian belajar pada penelitian ini dilakukan menggunakan bantuan program SPSS dan melihat koefisien alpha $(\alpha)$. Koefisien $\alpha$ pada angket kemandirian belajar adalah 0,88 sehingga angket dapat dikatakan reliabel.

Data yang akan dianalisis dalam penelitian ini meliputi skor kemandirian belajar siswa. Pengujian hipotesis dilakukan dengan menggunakan Independent Sample T-Test berbantuan program SPSS.

Dalam penelitian ini, pembelajaran matematika menggunakan media e-learning dengan metode guided discovery dikatakan efeketif ditinjau dari kemandirian belajar siswa pada pembelajaran matematika jika (1) terdapat perbedaan rata-rata skor kemandirian belajar antara kelas eksperimen dan kelas kontrol, dan (2) rata-rata skor kemandirian belajar siswa pada kelas eksperimen lebih unggul daripada rata-rata skor kemandirian belajar siswa pada kelas kontrol.

Untuk mengetahui apakah kelas eksperimen dan kontrol memiliki kondisi atau kemampuan awal yang sama, dilakukan uji hipotesis dengan menggunakan ANOVA pada data pretest. Untuk mengetahui manakah rata-rata skor yang lebih unggul antara kelas eksperimen dengan kelas kontrol dilakukan pengujian hipotesis dengan menggunakan ANOVA pada data postest.

Hipotesis pada penelitian ini yaitu $\mathrm{H}_{0} \quad$ : Terdapat perbedaan rata-rata skor kemandirian belajar antara kelas eksperimen dengan kelas kontrol.

$\mathrm{H}_{1}$ : Tidak terdapat perbedaan ratarata skor kemandirian belajar antara kelas eksperimen dengan kelas kontrol.

Sebelum dilakukan uji hipotesis, terdapat asumsi-asumsi yang harus dipenuhi yaitu data harus berdistribusi normal dan matriks kovarians populasi untuk $p$ variabel terikat harus sama (homogen).

\section{HASIL PENELITIAN DAN PEMBAHASAN}

Data hasil kemandirian belajar siswa dalam pembelajaran matematika diperoleh dari angket kemandirian belajar yang diberikan kepada siswa sebelum dan sesudah pemberian tindakan. Deskripsi data hasil angekt kemandirian belajar siswa disajikan pada Tabel 1. 
ISSN 2089-8703 (Print) Vol. 7, No. 3 (2018) 413-424

ISSN 2442-5419 (Online)

Tabel 1. Data Hasil Angket Kemandirian Belajar Siswa

\begin{tabular}{ccccc}
\hline \multirow{2}{*}{ Deskripsi } & \multicolumn{2}{c}{ Kelas Eksperimen } & \multicolumn{2}{c}{ Kelas Kontrol } \\
\cline { 2 - 5 } & Pretest & Posttest & Pretest & Posttest \\
\hline Rata-rata & 59,33 & 83,63 & 61,90 & 73,18 \\
Standar deviasi & 10,65 & 11,57 & 10,24 & 10,78 \\
Skor tertinggi & 81 & 109 & 80 & 107 \\
Skor terendah & 40 & 62 & 40 & 56 \\
Skor maksimum teoritik & 120 & 120 & 120 & 120 \\
Skor minimum teoritik & 24 & 24 & 24 & 24 \\
\hline
\end{tabular}

Hasil analisis statistik desktiptif angket kemandirian belajar siswa pada pembelajaran matematika disajikan pada Tabel 1 menunjukkan bahwa ratarata skor kemandirian belajar siswa sebelum (pretest) dan sesudah (postest) mendapat perlakuan pada kelas eksperimen masing-masing adalah 59,33 dan 83,63. Rata-rata skor pretest dan postest kemandirian belajar pada kelas kontrol masing-masing adalah 61,90 dan 73,18. Data tersebut menunjukkan bahwa terdapat peningkatan skor kemandirian belajar siswa setelah diberi perlakuan di kelas eksperimen sebesar 24,03 sedangkan pada kelas kontrol peningkatannya sebesar 11,28.

Frekuensi banyaknya siswa yang mencapai kategori level kemandirian belajar tertentu dihitung sesuai dengan rentang skor yang telah ditentukan. Tabel 2 menyajikan distribusi frekuensi dan persentase pengkategorian kemandirian belajar yang diperoleh pada pretest dan postest.

Tabel 2. Distribusi Frekuensi Skor Kemandirian Belajar

\begin{tabular}{|c|c|c|c|c|c|c|c|c|c|}
\hline \multirow{3}{*}{ Skor $(X)$} & \multirow{3}{*}{ Kriteria } & \multicolumn{4}{|c|}{ Pretest } & \multicolumn{4}{|c|}{ Postest } \\
\hline & & \multicolumn{2}{|c|}{$\begin{array}{c}\text { Kelas } \\
\text { Eksperimen }\end{array}$} & \multicolumn{2}{|c|}{$\begin{array}{c}\text { Kelas } \\
\text { Kontrol }\end{array}$} & \multicolumn{2}{|c|}{$\begin{array}{c}\text { Kelas } \\
\text { Eksperimen }\end{array}$} & \multicolumn{2}{|c|}{$\begin{array}{c}\text { Kelas } \\
\text { Kontrol }\end{array}$} \\
\hline & & $\mathrm{F}$ & $\%$ & $\mathrm{~F}$ & $\%$ & $\mathrm{~F}$ & $\%$ & $\mathrm{~F}$ & $\%$ \\
\hline $96<X$ & $\begin{array}{l}\text { Sangat } \\
\text { Tinggi }\end{array}$ & 0 & 0 & 0 & 0 & 6 & 15 & 1 & 2,56 \\
\hline \multirow{4}{*}{$\begin{array}{c}80<X \leq 96 \\
64<X \leq 80 \\
48<X \leq 64 \\
X \leq 48\end{array}$} & Tinggi & 1 & 2,5 & 1 & 2,56 & 20 & 50 & 6 & 15,38 \\
\hline & Sedang & 12 & 30 & 15 & 38,46 & 11 & 27,5 & 26 & 66,67 \\
\hline & Rendah & 23 & 57,5 & 21 & 53,85 & 3 & 7,5 & 6 & 15,38 \\
\hline & $\begin{array}{l}\text { Sangat } \\
\text { Rendah }\end{array}$ & 4 & 10 & 2 & 5,13 & 0 & 0 & 0 & 0 \\
\hline \multicolumn{4}{|c|}{$\begin{array}{l}\text { Berdasarkan Tabel } 2 \text { dapat } \\
\text { dilihat bahwa skor pretest kemandirian } \\
\text { belajar pada kelas eksperimen, terdapat } \\
2,5 \% \text { siswa berkategori tinggi, } 30 \% \\
\text { siswa berkategori sedang, } 57,5 \% \\
\text { berkategori rendah, dan } 10 \% \\
\text { berkategori sangat rendah. Skor posttest } \\
\text { kemandirian belajar pada kelas } \\
\text { eksperimen, terdapat 15\% berkategori } \\
\text { sangat tinggi, 50\% siswa berkategori } \\
\text { tinggi, 27,5\% siswa berkategori sedang, }\end{array}$} & \multicolumn{6}{|c|}{$\begin{array}{l}\text { dan } 7,5 \% \text { berkategori rendah. Skor } \\
\text { pretest kemandirian belajar pada kelas } \\
\text { kontrol, terdapat } 2,56 \% \text { siswa } \\
\text { berkategori tinggi, } 38,6 \% \text { siswa } \\
\text { berkategori sedang, } 53,85 \% \text { berkategori } \\
\text { rendah, dan } 5,13 \% \text { berkategori sangat } \\
\text { rendah. Skor posttest kemandirian } \\
\text { belajar pada kelas kontrol, terdapat } \\
2,56 \% \text { berkategori sangat tinggi, } \\
15,38 \% \text { siswa berkategori tinggi, } \\
66,67 \% \text { siswa berkategori sedang, dan } \\
15,38 \% \text { berkategori rendah. }\end{array}$} \\
\hline
\end{tabular}


diuji Data pretest dan posttest akan Independent Sample T-Test. Uji hipotesis pada data pretest bertujuan untuk mengetahui apakah kelas eksperimen dan kontrol memiliki kemampuan kemandirian belajar yang sama sebelum dilakukannya tindakan eksperimen. Sedangkan uji hipotesis univariat pada data posttest bertujuan untuk mengetahui efektivitas pembelajaran antara kelas eksperimen dan kelas kontrol terhadap ketiga variabel terikat. Uji hipotesis univariat dapat dilakukan jika sebaran data yang akan diuji memenuhi asumsi normalitas dan homogenitas.

Dari analisis data pretest pada kelas eksperimen, hasil Shapiro-Wilk diperoleh taraf signifikansi 0,60, dimana $0,60>0,05$ sehingga dapat disimpulkan bahwa data pretest pada kelas eksperimen berdistribusi normal. Taraf signifikansi pada kelas kontrol adalah 0,56 , dimana $0,56>0,05$ sehingga dapat dikatakan bahwa data pretest pada kelas kontrol berdistribusi normal. Dari hasil Lavene's Test, diperoleh taraf signifikansi adalah 0,86, dimana 0,86 > 0,05 sehingga dapat dikatakan bahwa data pretest pada kelas eksperimen dan kelas kontrol homogen.

Data pretest pada kelas eksperimen dan kelas kontrol berdistribusi normal dan homogen, sehingga dapat dilakukan uji hipotesis menggunakan Independent Sample TTest. Dari hasil Independent Sample TTest, diperoleh taraf signifikansi adalah 0,14 dimana 0,14>0,05 sehingga $\mathrm{H}_{0}$ diterima dan dapat disimpulkan bahwa tidak ada perbedaan rata-rata skor pretest pada kelas eksperimen dan kelas kontrol atau siswa pada kelas eksperimen dan kelas kontrol memiliki kemampuan kemandirian belajar yang sama sebelum dilakukan tindakan eksperimen.
Dari analisis data posttest pada kelas eksperimen, hasil Shapiro-Wilk diperoleh taraf signifikansi 0,38, dimana $0,38>0,05$ sehingga dapat disimpulkan bahwa data posttest pada kelas eksperimen berdistribusi normal. Taraf signifikansi pada kelas kontrol adalah 0,12 , dimana $0,12>0,05$ sehingga dapat dikatakan bahwa data posttest pada kelas kontrol berdistribusi normal. Dari hasil Lavene's Test, diperoleh taraf signifikansi adalah 0,77 , dimana 0,77 > 0,05 sehingga dapat dikatakan bahwa data posttest pada kelas eksperimen dan kelas kontrol homogen.

Data pretest pada kelas eksperimen dan kelas kontrol berdistribusi normal dan homogen, sehingga dapat dilakukan uji hipotesis menggunakan Independent Sample TTest. Dari hasil Independent Sample TTest, diperoleh taraf signifikansi adalah 0,00 dimana $0,00<0,05$ sehingga $\mathrm{H}_{0}$ ditolak dan dapat disimpulkan bahwa ada perbedaan rata-rata skor kemandirian belajar pada kelas eksperimen dan kelas kontrol. Dari Tabel 1 terlihat bahwa rata-rata skor posttest kemandirian belajar pada kelas eksperimen lebih unggul daripada kelas kontrol sehingga dapat dikatakan bahwa pembelajaran menggunakan media $e$ learning dengan metode guided discovery lebih efektif daripada pembelajaran yang hanya menggunakan metode guided discovery dalam hal kemandirian belajar matematika siswa.

Berdasarkan uji hipotesis diketahui bahwa siswa yang mendapat pembelajaran menggunakan media $e$ learning dengan metode guided discovery memiliki rata-rata skor kemandirian belajar yang lebih unggul daripada dengan siswa yang hanya mendapat pembelajaran menggunakan metode guided discovery. Atau dapat dikatakan pembelajaran menggunakan media e-learning dengan metode guided 
$\begin{aligned} & \text { discovery efektif ditinjau } \\ & \text { kemandirian belajar siswa } \\ & \text { pembelajaran matematika. }\end{aligned}$
pada

Kemandirian belajar kelas eksperimen lebih unggul daripada kelas kontrol, dikarenakan beberapa keuntungan dari e-learning. Seperti yang dikatakan oleh Repolusk (2009) bahwa keuntungan menggunakan $e$ learning dalam pembelajaran adalah siswa dapat mengakses informasi dan materi dengan cepat dan sederhana, meningkatkan komunikasi antar siswa, siswa dapat memantau kemajuan pembelajarannya sendiri, serta siswa dapat diberi kesempatan untuk lebih bertanggung jawab atas pengetahuannya sendiri.

Guru mengunggah tugas-tugas dan informasi terkait pembelajaran matematika pada media e-learning, sehingga siswa secara mandiri dapat mengakses informasi dan materi dengan cepat dan sederhana. Pembelajaran $e$ learning dapat meningkatkan komunikasi antar siswa, disini siswa dapat mandiri berkomunikasi atau berdiskusi dengan temannya mengenai materi matematika. Siswa dapat mengatur strategi pembelajarannya sendiri dengan kemudahan mengakses materi dan tugas serta kesempatan yang lebih untuk berkomunikasi dengan siswa lainnya. Contoh siswa membagikan informasi mengenai materi matematika dapat dilihat pada Gambar 1 dan contoh guru membagikan informasi mengenai matematika dapat dilihat pada Gambar 2. Kemandirian belajar tidak diperoleh secara spontan, tetapi dapat dikembangkan melalui partisipasi dalam pengalaman dan lingkungan yang memberi kesempatan bagi siswa untuk mengatur pembelajaran mereka sendiri (Kramarski \& Michalsky, 2009).

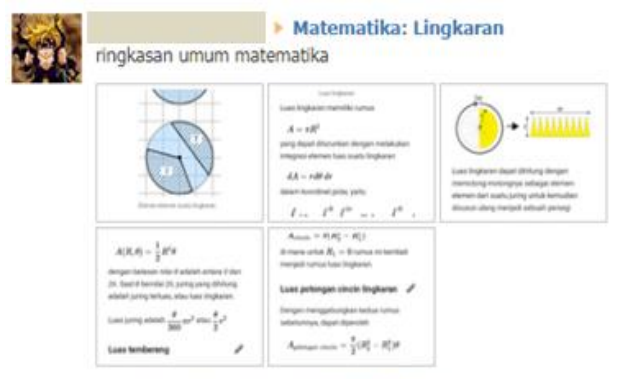

Gambar 1. Siswa Membagikan Informasi Mengenai Materi Matematika

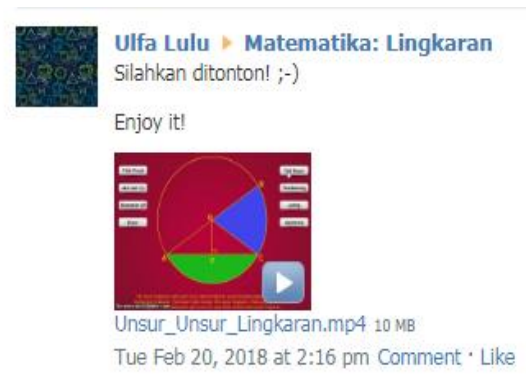

Gambar 2. Guru Membagikan Informasi

Mengenai Materi Matematika

Guru memberikan question of the day pada e-learning yang harus dijawab siswa setiap akhir pembelajaran, setelah siswa mengerjakan question of the day, secara otomatis siswa akan langsung mengetahui skor yang didapatkan. Sehingga dapat dikatakan siswa dapat memantau kemajuan pembelajarannya sendiri dengan melihat perkembagan skor yang didapat setiap guru memberikan question of the day, dimana memantau kemajuan pembelajaran atau mengevaluasi pembelajaran adalah salah satu indikator dari kemandirian belajar. Contoh perkembangan skor yang didapat siswa pada question of the day dapat dilihat pada Gambar 3. Pada Gambar 3, terlihat siswa memiliki tiga kesempatan untuk menjawab sebuah question of the day yang diberikan guru. 


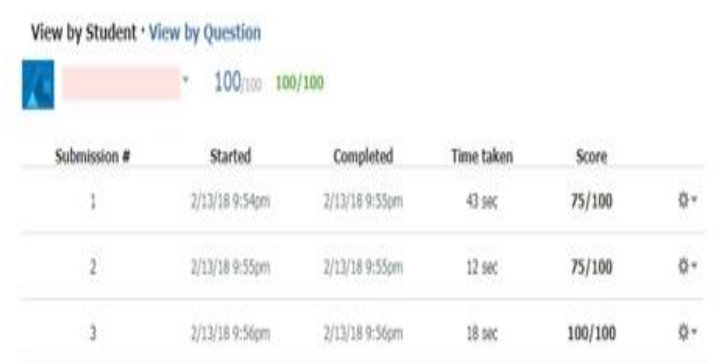

Gambar 3. Skor yang Didapat Siswa pada Question of The Day

Keuntungan e-learning lainnya adalah siswa dapat diberi kesempatan untuk lebih bertanggung jawab atas pengetahuannya sendiri, dimana siswa dilatih untuk bertanggung jawab atas tugas-tugas yang diberikan guru pada $e$ learning. Bertanggung jawab atas pengetahuannya sendiri adalah salah satu mengendalikan prilaku siswa yang merupakan salah satu indikator dari kemandirian belajar. Pembelajaran menggunakan media e-learning dapat membuat siswa mengembangkan kemampuan kemandirian belajar dengan bertanggung jawab atas pembelajaran mereka sendiri (Zhao \& Chen, 2016).

Penggunaan metode guided discovery juga memberikan peran dalam meningkatkan kemandirian belajar. Seperti yang kita lihat pada analisis data bahwa kemandirian belajar pada kelas kontrol meningkat dengan pembelajaran menggunakan metode guided discovery. Langkah-langkah guided discovery memiliki peran untuk melatih kemandirian belajarnya, khususnya pada tahap exploration dan presentation. Pada tahap exploration, siswa diberikan kesempatan untuk berdiskusi dengan kelompoknya. Pada tahap presentation, siswa diberi kesempatan untuk mempresentasikan diskusi kelompoknya serta mendiskusikan kembali dengan kelompok lain. Oleh karena itu, pada tahap exploration dan presentation dapat dikatakan melatih siswa untuk mandiri dalam belajar.

Penelitian ini juga didukung oleh penelitian-penelitian sebelumnya yang menunjukkan bahwa penggunaan teknologi dalam pembelajaan dapat melatih kemandirian belajar. Penelitian oleh Dabbagh dan Kitsantas (2005) menunjukkan bahwa pembelajaran melalui web dapat membantu meningkatkan kemampuan kemandirian belajar. Penelitian oleh Chen (2009) menunjukkan bahwa e-learning dapat melatih kemandirian belajar matematika siswa. Penelitian oleh Lazakidou dan Retalis (2010) menunjukkan bahwa computer based instructional dapat mengembangkan kemandirian belajar matematika siswa. Penelitian oleh Barak, Hussein-Farraj, dan Dori (2016) menunjukkan bahwa pembelajarn online memiliki efek positif terhadap pengembangan kemandirian belajar.

Hasil penelitian ini berimplikasi terhadap pemilihan pembelajaran yang sebaiknya dipilih oleh guru jika ingin melatih kemandirian belajar matematika siswa. Kesimpulan yang diperoleh dari hasil penelitian ini memberikan implikasi bahwa pembelajaran matematika menggunakan media $e$ learning dengan metode guided discovery cocok digunakan untuk melatih kemandirian belajar siswa.

\section{KESIMPULAN DAN SARAN}

Berdasarkan hasil penelitian dan pembahasan bahwa pembelajaran menggunakan media e-learning dengan metode guided discovery efektif ditinjau kemandirian belajar matematika siswa.

Saran dari penelitian ini adalah pembelajaran matematika menggunakan media e-learning dengan metode guided discovery dapat dipilih sebagai salah satu alternatif untuk melatih kemandirian belajar siswa pada pembelajaran matematika. 


\section{DAFTAR PUSTAKA}

Achera, L. J., Belecina, R. R., \& Garvida, M. D. (2015). The Effect of Group Guided Discovery Approach on the Performance of Students in Geometry. International Journal of Multidisciplinary Research and Modern Education (IJMRME). Vol. 1, No. 2, Hal 331-342

Alfieri, L., Brooks, P. J., Aldrich, N. J., \& Tenenbaum, H. R. (2011). Does Discovery-Based Instruction Enhance Learning? Journal of Educational Psychology. Vol. 103, No. 2, Hal 1-18

Artelt, C., Baumert, J., McElvany, N. J., \& Peschar, J. (2003). Learners for Life: Student Approaches to Learning. Results from PISA 2000. Paris, France: OECD.

Azka, R., \& Santoso, R.H. (2015). Pengembangan Perangkat Pembelajaran Kalkulus untuk Mencapai Ketuntasan dan Kemandirian Belajar Sswa. Jurnal Riset Pendidikan Matematika. Vol 2, No. 1, Hal 78-91.

Barak, M., Hussein-Farraj, R., \& Dori, Y. J. (2016). On-campus or Online: Examining SelfRegulation and Cognitive Transfer Skills in Different Learning Settings. International Journal of Educational Technology in Higher Education. Vol. 13, No. 35, Hal $1-18$

Chen, C. (2009). Personalized Elearning System with SelfRegulated Learning Assisted Mechanisms for Promoting Learning Performance. Expert Systems With Applications. Vol.
35, No. 5, Hal 8816-8829

Cullinane, A. (2010). Bloom's Taxonomy and Its Use in Classroom Assessment. National Centre for Execellence in Mathematics and Science Teaching and Learning. Vol. 1, No. 13, Hal 1-4

Dabbagh, N. \& Kitsantas, A. (2005). Using Web-Based Pedagogical Tools as Scaffolds for Self Regulated Learning. Instructional Science. Vol. 33, Hal 531-540

Dalgarno, B., Kennedy, G., \& Bennett, S. (2014). The Impact of Students' Exploration Strategies on Discovery Learning Using Computer-Based Simulations. Educational Media International. Vol. 51, No. 4, Hal 310-329

Day, S. L., \& Connor, C. M. (2016). Examining the Relations Between Self-Regulation and Achievement in Third-Grade Students. Assessment for Effective Intervention. Hal 1-13

de Corte, E., Depaepe, F., Eynde, P.O., \& Verschaffel, L. (2011). Students' Self-regulation of Emotions in Mathematics: An Analysis of Meta-Emotional Knowledge and Skills. ZDM International Journal on Mathematics Education. Vol. 43, No. 4, Hal 483-495

Etukudo \& Elijah, U. (2012). E-learning and Teachers Preparation in Science and Mathematics: The Paradigm for Utilization of Interactive Packages. European Scientific Journal (ESJ). Vol. 8, No. 13 8, Hal 172-177

Fadlelmula, F.K. (2010). Mathematical Problem Solving and SelfRegulated Learning. The International Journal of 
Learning. Vol. 17, No. 3, Hal 363-372

Follmer, D. J., \& Sperling, R. A. (2016. The Mediating Role of Metacognition in The Relationship Between Executive Function and Self-regulated Learning. British Journal of Educational Psychology. Hal 117

Garrison, D. R., \& Kanuka, H. (2004). Blended Learning: Uncovering Its Transformative Potential in Higher Education. Internet and Higher Education. Vol. 7, No. 2, Hal 95-105

Gunzenhauser, C., \& von Suchodoletz, A. (2015). Boys Might Catch up , Family Influences Continue: Influences on Behavioral SelfRegulation in Children from an Affluent Region in Germany Before School Entry. Early Education and Development. Vol. 26, No. 5-6, Hal 645-662

Imawan, O. R. (2015). Perbandingan antara Keefektifan Model Guided Discovery Learning dan Project-Based Learning pada Matakuliah Geometri. PYTHAGORAS: Jurnal Pendidikan Matematika. Vol. 10, No. 2, Hal 179-188

Jumaisyaroh, T., Napitupulu, E. E., \& Hasratuddin. (2015).

Peningkatan Kemampuan Berpikir Kritis Matematis Dan Kemandirian Belajar Siswa SMP melalui Pembelajaran Berbasis Masalah. Kreano, Jurnal Matematika KreatifInovatif. Vol 5, No. 2, Hal 157169.

Khan, Z. R. (2014). Using Innovative Tools to Teach Computer Application to Business Students - A Hawthorne Effect or Successful Implementation
Here to Stay. Journal of University Teaching \& Learning Practice. Vol. 11, No. 1, Hal 110

Kitsantas, A. (2013). Fostering College Students' Self Regulated Learning with Learning Technologies. Hellenic Journal of Psychology. Vol. 10, No. 3, Hal 235-252

Kramarski, B. \& Michalsky, T. (2009). Investigating Preservice Teachers Professional Growth in Self-Regulated Learning Environments Investigating Preservice Teachers' Professional Growth in SelfRegulated Learning Environments. Journal of Education and Practice. Vol. 101, No. 1, Hal 161-175

Ku, O., Chen, S. Y., Wu, D. H., Lao, A. C. C., \& Chan, T. (2014). The Effects of Game-Based Learning on Mathematical Confidence and Performance: High Ability vs Low Ability. Educational Technology \& Society. Vol. 17, No. 3, Hal 65-78

Lazakidou, G., \& Retalis, S. (2010). Computers \& Education Using Computer Supported Collaborative Learning Strategies for Helping Students Acquire Self-Regulated Problem-Solving Skills in Mathematics. Computers \& Education. Vol. 54, No. 1, Hal 3-13

Marchis, I. (2011). How Mathematics Teachers Develop Their Pupils' Self-Regulated Learning Skills. Acta Didactica Napocensia. Vol. 4, No. 2, Hal 9-14

Mayer, R. E. (2002). The Promise of Educational Psychology, Vol II Teaching for Meaningful Learning. Ney Jersey: Pearson 
Education.

McFarlane, A. (2001). Perspective on The Relationships Between ICT and Assessment. Journal of Computer Assisted Learniong. Vol 17, Hal 227-234

Pintrich, P. R. (2000). The Role of Goal Orientation in Self-Regulated Learning. In M. Boekaerts, P. R. Pintrich \& M. Zeidner (Eds.), Handbook of Self-Regulation. Burlington, MA: Elseiver Academic Press.

Repolusk, S. (2009). Interactive ELearning Materials in the Mathematics Classroom in Slovenia. Problem of Education in the 21st Century. Vol. 14, Hal 94-108

Rohendi, D. (2012). Developing Elearning Based on Animation Content for Improving Mathematical Connection Abilities in High School Students. International Journal of Computer Science Issues (IJCSI). Vol. 9, No. 4, Hal 1-5

Stevens J. (2009). Applied Multivariate Statistics for The Social Sciences. New York: Routledge.

Sunismi. (2015). Developing Guided Discovery Learning Materials Using Mathematics Mobile Learning pplication as an Alternative Media for The Students Calculus II. Jurnal Cakrawala Pendidikan. Vol 3, No. 3, Hal 334-346

Timmons, K., Pelletier, J., \& Corter, C. (2015). Understanding Children's Self-Regulation within Different Classroom Contexts Classroom Contexts. Early Child Development and Care.

Yang, E. F. Y., Liao, C. C. Y., Ching, E., Chang, T., \& Chan, T.-W.
(2010). The Effectiveness of Inductive Discovery Learning in 1: 1 Mathematics Classroom. In Proceedings of the 18th International Conference on Computers in Education (ICCE) (pp. 743-747). Putrajaya, Malaysia: Asia-Pasific Society for Computers in Education

Zhao, H., \& Chen, L. (2016). How Can Self-Regulated Learning Be Supported in E-learning 2.0 Environment: a Comparative Study. Journal of Educational Technology Development and Exchange. Vol. 9, No. 2, Hal 120

Zimmerman, B. J. (1990). SelfRegulated Learning and Academic Achievement: An Overview. Educational Psychologist. Vol. 25, No. 1, Hal 3-17 